\title{
Sürgün Bölgelerini Yeniden Düşünmek: İleri Marjinalliğin Teşkilinde Sınıf, Etnisite ve Devlet ${ }^{*}$
}

*

\author{
Loïc Wacquant \\ Kaliforniya Üniversitesi \\ Çeviren: Aksu Akçaoğlu
}

\section{Öz}

Sanayi-sonrası kentte sürgün, 'şehir içi mahalleler', 'gettolar', 'yıkıntılar', 'girilmez bölgeler', 'sorunlu muhitler' veya basitçe 'sert mahalleler' gibi kimi zaman gerçek kimi zaman da hayali çok çeşitli ve bulanı, özgün sosyo-mekânsal formasyonlara işaret eder. Bu mekânları nasıl karakterize etmeli ve ayrıştırmalıyız; güzergâhlarını (doğuşlarını, gelişimlerini, çöküşlerini ve ölümlerini) nasıl açıklamalıyız; üzerlerine yapışan damganın kaynă̆ı nedir ve ne tür bir sınıf, etnisite ve devlet kümelenmesini somutlaştırıp işaret etmektedir? Bunlar, benim Kent Paryalar (Wacquant, 2014) başlıklı kitabımda, neoliberalizmin hüküm sürdüğ̈̈ çă̆da, Amerika'daki kara gettoyla Avrupa işçi sınıfı banliyölerinin güzergahlarını metodik bir şekilde karşılaştırarak cevap aradığım sorulardır. Bu makalede, yeni bir yüzyılın eşiğinde kutuplaşmış metropolisteki sembolik, toplumsal ve fiziksel uzamlar arasındaki bulanık bağlantıya dair kavrayışımızı daha da genişletmek için, ileri marjinalliğin kıta aşırı sosyolojisini yeniden ele alıyorum. Buna ek olarak, karşılaştırmalı kent çalışmaları için faydalı olduğunu düşündüğ̈̈̈m, Bourdieu sosyolojisinin temel ilkelerine ışık tutuyorum.

Anahtar kelimeler: Kent yoksulluğu, sürgün, getto, etnik kümelenme, prekarya, bölgesel damgalama, ileri marjinallik, devlet, Bourdieu.

\footnotetext{
* Makalenin İngilizce aslı için bakınız: Wacquant, Loïc. 2016. "Revisiting the Territories of Relegation: Class, Ethnicity and State in the Making of Advanced Marginality". Urban Studies 53(6): 1077-1088.
}

idealkent @ Kent Araştırmaları Dergisi (Journal of Urban Studies)

http://idealkentdergisi.com

Geliş Tarihi Received Date: 07.03.2019 Kabul Tarihi Accepted Date: 20.04.2019 


\title{
Revisiting Territories of Relegation: Class, Ethnicity and Statein the Making of Advanced Marginality \\ *
}

\author{
Loïc Wacquant \\ University of California
}

Translated by Aksu Akçaoğlu

\begin{abstract}
In the postindustrial city, relegation takes the form of real or imaginary consignment to distinctive sociospatial formations variously and vaguely referred to as 'inner cities,' 'ghettos,' 'enclaves,' 'no-go areas,' 'problem districts' or simply 'rough neighborhoods'. How are we to characterise and differentiate these spaces; what determines their trajectory (birth, growth, decay and death); whence comes the intense stigma attached to them; and what constellations of class, ethnicity and state do they both materialise and signify? These are the questions I pursued in my book Urban Outcasts (Wacquant, 2008a) through a methodical comparison of the trajectories of the black American ghetto and the European working-class peripheries in the era of neoliberal ascen-dancy. In this article, I revisit this cross-continental sociology of 'advanced marginality' to tease out its broader lessons for our understanding of the tangled nexus of symbolic, social and physical space in the polarising metropolis at century's threshold in particular, and for bringing the core principles of Bourdieu's sociology to bear on comparative urban studies in general.
\end{abstract}

Keywords: Urban poverty, relegation, ghetto, ethnic cluster, precariat, territorial stigmatization, advanced marginality, state, Bourdieu 
Sürgün, bir bireye, gruba ya da kategoriye, belirsiz ya da aşağı bir konumu, koşulu veya muhiti tahsis etmeyi ifade eder (sözcüğün İngilizce karşıllğı geç Orta Çağ İngilizcesindeki relegaten fiilinden türemiştir ve bir yerden kovmayı, def etmeyi ifade etmektedir). Sanayi-sonrası kentte sürgün, 'kent içi mahalleler', ' 'gettolar', 'yıkıntılar', ' 'girilmez bölgeler', 'sorunlu muhitler' veya basitçe 'sert mahalleler' gibi kimi zaman gerçek kimi zaman da hayali çok çeşitli ve bulanık, özgün sosyo-mekânsal formasyonlara işaret eder. Bu mekânları nasıl karakterize etmeli ve ayrıştırmalıyız; güzergâhlarını (doğuşlarını, gelişimlerini, çöküşlerini ve ölümlerini) nasıl açıklamalıyız; üzerlerine yapışan damganın kaynağı nedir ve ne tür bir sınıf, etnisite ve devlet kümelenmesini somutlaştırıp işaret etmektedir? Bunlar, benim Kent Paryaları (Wacquant, 2014) başlıklı kitabımda, neoliberalizmin hüküm sürdüğü çağda, Amerika'daki kara gettoyla Avrupa işçi sınıfı banliyölerinin güzergahlarını metodik bir şekilde karşılaştırarak cevap aradığım sorulardır. ${ }^{1}$ Bu makalede, yeni bir yüzyılın eşiğinde kutuplaşmış metropolisteki sembolik, toplumsal ve fiziksel uzamlar arasındaki bulanık bağlantıya dair kavrayışımızı daha da genişletmek için, ileri marjinalliğin kıta aşırı sosyolojisini yeniden ele alıyorum. Buna ek olarak, karşılaştırmalı kent çalışmaları için faydalı olduğunu düşündüğüm, Bourdieu sosyolojisinin temel ilkelerine 1şık tutuyorum.

Yoksulluk bölgeleri ya da alt gelir grubu toplulukları yerine kentsel sürgün kavramını kullanmaktaki amaç, uygun araştırma nesnesinin, mekânın kendisinden ve sakinlerinden ziyade, marjinal bölgelerde yaşayan bireyleri seçen, zorlayan ve idame ettiren çok boyutlu yapısal süreçler kadar bu bölgelerde geliştirilen sosyal ağlar ve kültürel formlar olduğunda israr etmektir. Sürgün, bireysel bir durum değildir, kolektif bir edimdir; (ekonomik, sosyal ve sembolik iktidarla kurulan) topluluklar arası bir ilişkidir, bireylerin geçici niteliği değildir. Bunun bize hatırlatması gereken şey, akademideki mevcut kusurlu gerçekçilikten ve sıradan yaygın kanaatlerden kaçınmak olmalıdır; marjinalliğin sosyolojisi (çoğu kez sadece kağıt üzerinde var olan) zayıf 'gruplara' saplanıp kalmamalıdır; daha ziyade bu grupların farz edilen mensuplarının eklemlendiği konumlar ağını üreten, yeniden üreten ve dönüştüren kurumsal mekanizmalara odaklanmalıdır. Bu aynı zamanda, sözünü ettiğimiz farz edilen yoksunluk bölgelerinin sosyal ve mekânsal kurulumu hakkında şüpheci kalmamız için bir uyarıdır. Özellikle de, bu mekânlara ve onların dışına doğru açlan toplumsal güzergâhların çeşitliliği düşünüldügü̈nde, ortaya çıkan toplumsal varlığı (en basit tanımıyla paylaşılmış bir çevreyi ve kimliği, yatay toplumsal bağları ve ortak çıarları ifade eden) bir top- 
luluk, hatta bir kader ortaklığı olarak bile kabul edemeyiz. ${ }^{2}$ Herhangi bir toplumda, düşük gelirli bireylerin (sanatçlar ve yaşlılar, hizmet sektörü işçileri ve yüksek lisans öğrencileri, evsizler ve kaçak göçmenler gibi) heterojenliği ve ancak bir istatistiksel kategori olarak anlam ifade ettikleri düşünüldüğünde, gelir düzeyini ya da maddi yoksunluğu rakipsiz görme ve bölme ilkesi olarak görmemeliyiz.

Kent Paryaları Birleşik Devletler ve Batı Avrupa'da Fordist-Keynesçi çağın kapanmasını takiben kentlerde beliren 'aşağıdan kutuplaşma'nın nedenlerinin, biçimlerinin ve sonuçlarının izini süren kuramsal ve ampirik araştırmaların bütününden oluşur ve sanayi-sonrası prekaryanın ileri toplumların sürgün mahallelerinde toplanmasının yol açtı̆̆ açmazları tespit eder. Kitap, Amerika'daki kara gettoda 1960'lardan sonra yeniden alevlenen isyan hareketleriyle, sanayisizleşme çağında Fransız banliyölerindeki işçi sınıfı mahallelerinde gözlemlenen dağılmayı karşılaştırabilmek için saha notlarından istatistiki ve tarihsel verilere uzanan geniş bir alana Bourdieu sosyolojisinin temel ilkelerini uygular. Bu makalede, üç temel tezimi ortaya koyup, sanayisonrası kentte yoksulluk, mekân ve iktidar arasındaki ilişkiyi aydınlatmada yardımcı olmasını umarak kentsel marjinalliğin karşılaştırmalı çalışmaları için yenilenmiş bir analitik çerçeve sunuyorum.

\section{Gettodan Hipergettoya: Siyah Marjinalliğinin Siyasi Kökleri}

Kara gettonun eninde sonunda uğrayacağı düşünülen kör talih, yüzyıl dönümünde kentsel dönüşüme dair sosyal ve bilimsel düşlerde öylesi merkezi bir yer edinmişti ki, çalışma kaçınılmaz olarak Amerikan metropolisindeki ırk, sınıf ve mekânın yeniden düzenlenişine açıklık getirerek başlar. ${ }^{3}$ Amerikan kıyılarında, 'şehir içi mahallelerde ${ }^{\text {'ii }}$ aniden patlak veren ve öngörülemeyen karmaşa, siyasi endişelerin ve akademik ihtilafların kaynağına dönüşmüştü. Batı Avrupa'da ise ayrışmanın, ihmalin ve sapkınlığın patolojik mekânı olarak Amerika' dan ithal edilmiş bulanık 'getto' imgesi -özellikle de 1992 ilk baharında Los Angeles'ta patlak veren isyanların ardından daha da yoğunlaşarak- kutuplaşan kentte göç ve eşitlik üzerine yürütülen medyatik, siyasi ve entellektüel tartışmalarda yayginlaştı ve böylelikle de konunun özünü buharlaştırdı.

\footnotetext{
ii Şehir içi mahalle kavramı, siyahlara dayatılmış etno-ırksal bir kapatma aracı olarak, getto gerçekliğini gizleyen coğrafi bir hüsn-ü tabirdir.
} 
Dolayısıyla, ilk tez, Birleşik Devletler'de gettodan hipergettoya tarihi geçişin taslağını çıkarır ve ırksallaşmış marjinalliğin yeniden üretiminde devlet yapısının ve siyasetin merkezi rolünü vurgular. 1930'ların Chicago Okulu'ndan miras kalan 'çözülme' kavramını rafa kaldıran ve 1980'lere kadar ırk ve yoksulluk çalışmalarını etkisi altına alan 'sınıfaltı' masalını (yapısal, davranışsal ve neo-ekolojik türevleriyle birlikte) reddeden Kent Paryaları, sivil haklar hareketinin ardından çöken siyah Amerikan gettosunun yerini yeni bir örgütsel kümelenmeye bıraktığını gösterir: Hipergetto. Daha açık olmak gerekirse, 1915-19654 arası Afrika kökenli Amerikan kentlilerini, bizzat kendilerinin inşa ettiği ortak kurumlar ağına iten, merkezinde kurulduğu beyaz kent tarafından tecrit edilen 'Siyah Metropolü', ardında ikili bir sosyo-mekânsal oluşum bırakarak çöküşe geçti.

$\mathrm{Bu}$ merkezsiz oluşumun bir ucunda, tarihi getto kalıntılarının ekonomik işlevini yitirmiş, hem ırksal hem de sınıfsal olarak ayrıştırılmış,çözülmenin korkuyla iç içe geçtiği çorak topraklarında siyah işçi sınıfının prekaryalaşmış fraksiyonlarını kapatan hipergetto (HiGe) bulunur. Diğer ucundaysa, beyazların uydu kentlere doğru kitlesel göçüyle boşalmış muhitlerde yeni filizlenen ve sakinlerinin çoğu kamu sektöründe çalışan siyah orta sinıf mahalleleri (SOSM) bulunur. 1. Dünya Savaşı'ndan 1960'lardaki isyanlara kadar geçen süreçte mekân, kendi içinde tabakalaşmış Afrika kökenli Amerikalılar topluluğunu bütünleştirirken, şimdiyse kural tanımayan alt sınıf kardeşlerine göz kulak olmakla görevlendirilmiş siyah orta sınıfların istihdam edildiği devletin sosyal kontrol kurumlarını da desteğiyle, eski bütünleşmiş topluluğu parçalara ayırır. ${ }^{5}$ Fordizmin biçimlendirdiği yarım yüzyılın, sembolik, toplumsal ve fiziksel uzamlara kazınmış Beyaz:Siyah :: Kent:Getto şeklinde özetlenebilecek karşıtlıkları, parçalı bir mantığı takip ederek hipergetto sakinlerini iki kat daha fazla majinelleştiren ve tabi kılan, Beyaz:Siyah:: Kent:SOSM:HiGe şeklinde özetlenebilecek çok daha karmaşık ve gerilim yüklü bir yapı tarafından aşılmıştır. Amerikan sosyolojisinin ırk ve yoksulluk ilişkisinde devletin rolünü görmezden gelen ana akım yaklaşımlardan kopan Kent Paryaları, hipergettolaşmanın ekonomik olarak zayıf, siyasi olaraksa aşırı belirlenmiş olduğunu tespit eder. Siyah yoksunluğunun hipergettoda sosyal ve mekânsal yoğunlaşmasının arkasındaki ayırd edici itki, (William Julius Wilson'ın (1996) iddia ettiği gibi) 'işin yok olması' ya da (Douglas Massey'in ileri sürdüğü gibi (Massey ve Denton, 1993)) 'hiperayrışma' değildir (fakat yine de bu iki faktörün incelediğimiz süreçte hiç etkisi olmadığı sonucuna varılmamalı). Komünal gettonun çöküşünün arkasındaki temel itki, istih- 
dam, refah, eğitim, konut ve sağlık gibi konularda hükümet politikalarının -federal devlet, eyalet ve yerel yönetim ölçeğinde- kenti terk etmesi ve böylelikle kent merkezindeki kamu kurumlarının çöküşüdür. Buradan çıkarmamız gereken sonuç, Amerikan metropolündeki sınıf ve (reddedilmiş etnisite olarak) ırk açmazının, kent yoksullarının hayat stratejilerini ve alternatiflerini kati suretle biçimlendiren bir tabakalaşma ve sınıflandırma faili olarak devletin işleyişini hesaba katmadan çözülemeyeceğidir.

\section{‘Örtüşme Tezi'nin Açıklanması ve Çürütülmesi}

Kent Paryaları'nın -temel tezini içeren- ikinci bölümü, okuyucuyu Atlantik'in karşı yakasına taşıyıp, sanayi-sonrası Avrupa'da sınıf, etnisite ve devlet arasındaki, Amerika'dakini andıran, mekânsal bağlantıya ışık tutar. Kent Paryaları, son yirmi yıldır tüm kıta Avrupa'sını, 2000'lerden6 itibaren de İskandinav ülkelerini kırıp geçiren gettolaşma söyleminde derin bir yarık açarak, Fransa ve komşu ülkelerdeki kentsel yoksunluk bölgelerinin Amerikan gettosu olmadığını gösterir. Yüzeydeki sosyal morfolojideki (nüfus yapısı, yaş dağılımı, göreceli işsizlik ve yoksulluk düzeyleri gibi) ve bir metropolü teşkil eden mekânların maddi ve sembolik hiyerarşisinde en altta bulunmaktan kaynaklanan (aşağılanma, kapatılma ve kusurluluk hisleri gibi) temsillerdeki benzerliklere rağmen, siyah Amerikan gettosunun kalıntılarıyla Avrupa işçi sınıfı banliyöleri, yapısal, işlevsel ve ölçek farklılıkları kadar maruz kaldıkları siyasi müdahalelerdeki farklılıklar nedeniyle de büyük ölçüde ayrışırlar.

Özetlemek gerekirse, kara gettoya yönelik tiksinme, etnisite (E) tarafından belirlenir, 1970'lerde hipergettonun ortaya çıkmasının ardından sınıf (S) tarafından biçimlendirilir ve yüzyıl boyunca devlet (D) tarafından yoğunlaştırılır. Sözünü ettiğimiz bu ilişki, geometrik bir formülle şu şekilde ifade edilebilir: [(E $>S) \times D]$. Bunun aksine, Batı Avrupa kentlerinin banliyölerindeki sürgün, sınıfsal konum tarafından yönlendirilir, etno-ulusal aidiyet tarafından biçimlendirilir ve devlet yapıları ve politikaları aracılığıyla hafifletilir. Avrupa kentlerindeki sürgün bölgelerinin arkasındaki temel dinamikler şu formülle özetlenebilir: $[(\mathrm{S}>\mathrm{E}) \div \mathrm{D}]$. Bu formül, etnik bir baskının bütün sınıfsal hiyerarşiye benzer biçimde uygulanmasıyla, kendi içinde genişletilmiş iş bölümü ve paralel kurumlar geliştiren, 'kent içinde bir göçmenler kenti' üretmez. Başka bir deyişle, Avrupa örneği, aşağılanmış bir nüfusu sosyal olarak dişlamak ve ekonomik olarak sömürmek gibi işlevleri yerine getiren 20. Yüzyılın ortasındaki siyah Amerikan gettosuyla örtüşmez. 
Kentteki çeşitli yoksunluk mekânlarını 'getto' etiketi altında toplamak, Kent Paryaları'nın gidermeye çalıştığı üç hatayı doğurur ve yaygınlaştırır. İlk hata, getto kavramının 'kentsel çoraklaşma' düşüncesini pompalayacak ve kamu vicdanını şoka uğratacak bir biçimde, basit bir retorik araç olarak kullanılmasına dayanır. ${ }^{7}$ Fakat getto, ayrışma, yoksunluk, harap durumdaki konutlar, çökmüş kurumlar ve suç ve kötülüğün yaygınlaşmasıyla tanımlanabilecek bir çözülme bölgesi ya da 'kötü bir mahalle' değildir. Getto daha ziyade, damgalanmış bir kategoriyle, bu etiketlenmiş nüfusun kaba tahakküme karşı kendi içinde örgütlenmesine olanak tanıyarak, korunaklı bir limana dönüşen mekân arasındaki karşılıklı ilişkiden doğan, etno-ırksal ka-

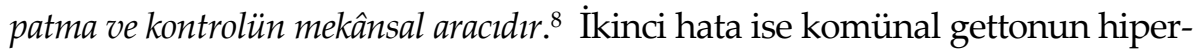
gettoyla karıştırılmasına dayanır: Yoksullaşma, ekonomik kayıt dışılaşma, kurumsal çölleşme ve gündelik hayatın pasifleşmesi gettonun özellikleri değildir. Bunlar olsa olsa, gettonun bozulmasımın ve yalnılaşmasının semptomu olabilir.

Üçüncü hata ise Avrupa'daki geleneksel işçi sınıfı bölgelerinin geçirmiş olduğu evrimin yanlış okunmasına dayanır. Sanayi-sonrası sürgün döneminde, bu itibarsızlaştırılmış bölgeler, etnik olarak heterojenleşirken, sömürge-sonrası göçmenlerin kentteki yayılımı dağınıklaştı (gerçi küçük muhitlerdeki yüksek göçmen yoğunluğu bile medyanın ilgisini çekmeye, siyasetçileri endişelendirmeye yetti). ${ }^{9}$ Göçmen muhitlerindeki örgütsel ekoloji seyrekleşti, yoğunlaşmadı; sınırları ise geçirgenleşti ve sınıfsal hiyerarşide yukarı doğru hareketlenen sakinleri tarafından rutin bir biçimde aşıldı. İslam'ın yabancı kökenli kent paryaları için ortak bir dil sağlayıp, tersine asimilasyonun fitilini ateşleyeceğine dair (Liogier, 2012), tüm Avrupa'da yayılan fantastik korkuya rağmen, geleneksel işçi sınıfı bölgeleri göçmenler için kolektif kimlik yaratmakta başarısız oldu. Bu beş boyutun her birinde, Avrupa metropollerindeki sürgün bölgeleri, bir sosyo-mekânsal kapatma aracı olarak getto dokusundan istikrarlı bir biçimde uzaklaşmaktadır: Getto kavramını kullanmakta ssrar edilecekse, bu muhitler en fazla anti-getto olarak adlandırılabilir.

Kötü durumdaki toplu konutları, çaresiz hane halklarını ve sömürge-sonrası göçmenleri yoğun olarak içeren alt sınıf bölgelerinin getto olmadığını söylemek, çağdaş Avrupa'da eşitsizliğin yapılandırılmasında etnisitenin rolünün reddedilmesi anlamına gelmez. Kent Paryaları, yabancı düşmanlı̆̆ını aşılayan zehirli ifadelerin sıradanlaştığını ve göçmenlerin emek piyasasında ulusal aidiyet temelinde ayrımcılık gördüğünü ya da doğrudan dışlandıklarını tereddütsüz bir biçimde vurgular. Dahası, etnisitenin, tüm kıta Avrupa'sında olduğu gibi, 'Fransız sosyal hayatında çok daha dikkat çekici bir göstergeye' 
(ss. 195-196) dönüştügüünü kabul eder. Fakat bilişsel belirginlik, sosyal neden değildir. Etnisitenin siyaset ve medya alanlarında revaçta olması, toplumsal ve kentsel yapıdaki konumun ve güzergâhın belirlenimindeki ağırlığının arttığı anlamına gelmediği gibi, sıradan etkileşimleri ve gündelik deneyimleri rutin olarak eğip büktüğü anlamına da gelmiyor. ${ }^{10}$ Dahası, etnik yarılmalar dalgalandığında ve sosyal ilişkileri damgaladığında, her yerde aynı maddi forma büründüğünü varsayamayı.

Gettolaşmanın, Avrupa kentlerinin yoksullaşmış ve damgalanmış bölgeleri için açıklayıcı olmadığııı ileri sürmek, Batı Avrupa ve Birleşik Devletler arasındaki kökleşmiş devlet, vatandaşlık ve kentleşme farklılıklarının da etkisiyle, etno-ırksal sınıflandırma ve tabakalaşma biçimlerinin (ve bunların mekâna kazınma tarzlarının) Atlantik'in her iki kıyısında farklılaştığını belirtmekten ibarettir. Eski dünyanın banliyölerinde, göçün tetiklemesiyle filizlenen sembolik bölünmeler, Weber' in parçalı cemaatler kavramında ima edildiği gibi, ekolojik olarak parçalı fakat kültürel ve siyasi olarak bütünleşmişs ${ }^{11}$ 'etnik cemaatler' üretmez (bundan farklı olarak Birleşik Devletler tarihinin akışında yalnızca Afrika kökenli Amerikalılar için, aşağı-soy temelli yarılmayı ifade eden ırk kavramı 'etnik bir cemaat' yaratır). Etnisite, kurumsal düzlemler ve sınıfsal yapının farklı düzeyleri boyunca tutarsız bir biçimde işleyen değişken ve karmaşık kriterler tarafından tanımlanır. Bu nedenle de, sembolik, toplumsal ve fiziksel uzamlarda sınırları birbiriyle uyumlu bir gettolaşma dinamiği üretemez. ${ }^{12}$

\section{‘Oluşum Tezi'ni Formüle Etmek ve Onaylamak}

Siyah Amerikan gettosuna özgü dokuların Atlantik'in karşı yakasında yayıldığ1 tezini çürütmek, sanayinin gelişip güçlendiği, kabaca 1880-1980 arasında hüküm süren dönemden farklı, yeni bir kentsel marjinallik rejiminin oluştuğu tezini açıklğa kavuşturmayı gerektirir. Kent Paryaları'nın üçüncü bölümü, ileri marjinalliğin ${ }^{\text {iii }}$ bu yükselen biçiminin ideal-tipik tarifini geliştirir. ${ }^{13}$ Karşılaştırmalı bir bakış, ileri marjinalliğin altı eş zamanlı özelliğini ortaya koyarken (8. Bölüm), boylamsal bir bakış, mesleki yapının kutuplaşmasını ve devletin metalaşmayı teşvik edecek biçimde yeniden inşa edilmesini kapsayan dört ikna edici dinamiği gün yüzüne çıkarır (9. Bölüm). Burada, ileri marjinalliğin

\footnotetext{
iii İleri marjinallik kavramı, güncel kent marjinalliğinin geçmişin bir kalıntısı olmadığı gibi, döngüsel ya da geçiş dönemine özgü bir marjinallik biçimi olmadığını da vurgular. İleri marjinallik, hem Birleşik Devletler'deki kara gettoyu hem de Batı Avrupa'nın geleneksel işçi bölgelerini bozuma uğratan, finans kapitalizminin derin yapılarında kök salmıştır.
} 
özgünlüğünü vurgulayabilmek için, bu özelliklerden, biri maddi diğeri sembolik, ikisine 1şık tutmak istiyorum.

Kentteki yeni marjinallik rejiminin en önemli maddi niteliği, mesleki yapının en dibindeki ücretli emeğin parçalanmasıdır. Son yirmi yıldır bütün gelişmiş ülkelerde ivme kazanan ve somutlaşan bu akım, istikrarsız, yarı-zamanlı, kısa süreli, düşük ücretli ve geleceği olmayan işlerin yaygınlaşmasını ifade eder (Cingolani, 2011; Kalleberg, 2011; Pelizzari, 2009). Yirminci yüzy1lın büyük bir bölümünde, işçi sınıfının yaşam ve hane halkı stratejileri 40-5060 formülü (60 yaşına kadar, yılda 50 hafta, haftada 40 saat çalışmayı ifade eden uluslararası ortalama) etrafında kurgulanmış sanayi istihdamına dayanırken, bugün güvencesiz hizmet proleteryasının vasıfsız kesimleri hem iş kıtlı̆̆ıyla hem de sözleşmeli çalışma bolluğuyla karşı karşıyadır ki bu da onları parçalara ayırıp istikrarsızlaştırır. Sosyal ufku, dinmeyen cefa ve çoğalan 'yoksul çalışanlar' üreten bölgesel işsizlik ve azgın güvencesizlik tarafından tıkanan bu kesimlerin zamansal ufku da daralmıştır. ${ }^{14}$

Bu çifte ekonomik ceza, özellikle sanayisizleşmenin tükettiği alt sınıf mahallelerde yaygindır. Örneğin Fransa'da 1992-2007 arasında güvencesiz işlerde (kısa süreli, geçici işlerde, kamu kurumlarındaki sözleşmeli işlerde ve stajyer olarak) çalışanların sayısı 1,7 milyondan 2,8 milyona sıçramıştır ki bu da ülkedeki aktif iş gücünün \%12,4'üne tekabül eder. Buna bir de \%7-\%10 arasında gidip gelen ve 15-24 yaş aralığındaki nüfusta \%17'den \%49'a firlayan işsizlik oranını eklemeliyiz (Maurin and Savidan, 2008). Fakat, Fransız kent politikasının resmi olarak 'hassas kentsel bölge' (ZUS) adı altında sınıflandırdığ 1571 birimde, 1990'da \%40 olan işsiz ya da güvencesiz işlerde çalışan gençlerin oranı 2000 'den sonra \%60'ın da üzerine çıkmıştır.

Parçalanmış ücretli emek, daha da yaygınlaşan yoksulluktan korumak şöyle dursun, toplumsal hiyerarşide aşağ 1 düşmekten ve okullarda artan rekabet ve diploma-iş-maaş arasındaki bağlantının gevşemesinden dolayı statülerini çocuklarına aktaramamaktan korkan alt-orta sınıf için öznel, sanayisonrası proleterya için ise nesnel bir sosyal güvencesizlik taşıyıcısıdır. Kent Paryaları, sınıf yapısıyla kent yapısı arasındaki bağlantıyı en baştan yeniden kurma çağrisı olduğu kadar, yoksulluğun mekânsal boyutuna odaklanan (örneğin 'mahalle etkisi' başlığı altında toplanabilecek) $)^{15}$ çalışmalara, erken 21. yüzyılın sosyal sorununa karşı hassasiyet uyarısıdır: Sözünü ettiğim bu toplumsal sorun, sosyal güvencesizliğin, kent prekaryalarının yaşadıkları bölgeler ve yaşam stratejileri üzerindeki etkilerinin ve sınıf hiyerarşisinin dibinde yayginlaşmasınun normalleştirilmesidir. 
Fakat, prekaryanın sırtındaki tek yük, 'Mcİsler' in [McJobs](Fransa'da petits boulots, Almanya'da Billig-Jobs, Birleşik Krallık'ta zero-hour contracts, İtalya'da lavoretti, Portekiz'de biscate) insafsız yayılımı değildir. İkinci yük, sosyal istikrarsızlığı derinleştirip, kültürel yükünü daha da ağırlaştıran sembolik vektördür: bölgesel damgalama. Bourdieu'nün (1990) sembolik iktidar kuramıla Goffman'ın (1964) kusurlu kimliklerin yönetimi analizini birleştirerek biçimlendirdiğim bu kavrama, yüzyıl dönümünde kentsel sürgün bölgelerine iliştirilmiş mekânsal lekenin, bu bölge sakinlerinin benlik algısını ve eylem [repertuarını] nasıl etkilediğini anlamak, gelişmiş ülkelerdeki özel girişimlerin, kamu bürokrasilerinin ve devlet politikalarının yoksun nüfus ve bölgelere karşı tavrını nasıl biçimlendirdiğini tespit edebilmek için başvuruyorum.

İlk olarak, bölgesel lekenin siyah Amerikan gettosunun ve Fordist-Keynesçi döneme özgü Avrupa işçi sınıfı banliyölerinin çözülmesine paralel ortaya çıkan özgün, yeni ve genelleşmiş bir olgu olduğunu ve esas olarak yoksulluk, aşağı görülen etnik köken ve somut sapma gibi geleneksel damgaların üzerine giydirildiğini belgelendiriyorum. Kitap yayımlandı̆̆ından beri, çok sayıda çalışma, mekânsal damganın üç farklı kıtanın şehirlerinde yükselişini, dirayetini ve karmaşıklaşmış yansımalarını belgeledi. ${ }^{16}$

Ardından, mekâna yönelik aşağılamanın, marjinallik dinamiklerinin altında yatan nedensellikleri, farklı düzeylerde işleyen bilişsel mekanizmalar vasıtasıyla, gerçek kaynağından uzaklaştırdığını gösteriyorum. Sözünü ettiğim bu mekânsal aşağılama, sürgün bölgeleri sakinlerini içinde bulundukları durumla başa çıkabilmek için karşılıklı dışlama, etrafındakileri kötüleme, özel alana çekilme ve mahalle değiştirme gibi stratejilere yönlendirir. Bütün bu stratejiler, kimliksizleşmeyi ve çekingenliği teşvik edip, yerel sosyal bağları gerginleştirerek sosyal kontrol ve kolektif eylem kapasitesini azaltır. Dahası, bu mekânsal itibarsızlaştırma, sivil arenadaki, ekonomideki (zira firmalar yatırım yapacakları bölgeyi seçerken ve işçi alımı yaparken adrese göre ayrımcılık uygularlar) ${ }^{17}$ ve sosyal yardım, sağlık ve güvenlik gibi kamusal hizmetlere erişimdeki (yasa uygulayıcıları alt sınıf muhitlerde nezaketsiz ve sert davranmayı hak bilirler) görevlilerin algı ve davranışlarını çarpıtır. Bölgesel damgalama, toplumsal uzamin tepe noktalarında, kültürel üretim uzmanlarının, örneğin gazetecilerin ve akademisyenlerin, çalışmalarını biçimlendirir; devlet elitlerinin düşüncelerine sirayet eder ve böylelikle marjinalliği yukarıdan tanımlayıp, yükünü aşağıya yayan bütün kamu politikalarını biçimlendirir. Buhranlı sosyal konut kümelerini, 'getto-kent', 'batık muhit' ya da 
'getto-bölgesi' biçiminde etiketlemek, bu bölgeleri daha en başından birer kentsel arafa dönüştürür; farklı teşhislerin önünü tıkayarak yıkım, sürgün veya cezai kapatma uygulamalarını teşvik eder. ${ }^{18}$

Son olarak, bölgesel damgalamanın hem toplumsal uzamın hem de fiziksel uzamın alt kesimlerinde sınıfsal çözülmeye aktif biçimde katkıda bulunduğunu ileri sürüyorum. Kutuplaşmış metropoliste, çöküşteki yoksunluk bölgelerini kuşatan bu zehirli temsiller, sanayi-sonrası proleteryanın istihdam güvencesizliğinden, kategorik refahtan sözleşmeli çalışma refahına geçişten ve vasıfsız işlere erişimde dahi orta öğretim gerekliliğinin evrenselleşmesinden kaynaklanan nesnel parçalanmasını pekiştirir. Mekânsal damga, sakinlerini yurt edinme ve kendi sözlerini söyleme becerilerinden mahrum bırakır; dışarıdan dayatılan zehirli bir kimliği yük edindirir. Bütün bunlara, bir de eğitimli orta sınıflar etrafında yeniden konumlandırılan siyaset alanındaki değer yitimi ve sembolik ufalanma da eklenir. Uzun lafın kısası, prekarya, Guy Standing'in (2011) ileri sürdügü gibi 'yeni tehlikeli sınıf' değildir. Daha ziyade, sadece istikrarlı bir hayat sürmekten değil, kendi temsilini üretmekten de mahrum bırakıldığı için, bir türlü kendisinin farkına varamayan, henüz doğmadan ölmüss bir kolektiftir. Ortak bir dilden ve sosyal pusuladan mahrum kalan, kendi içinde bölünen prekarya mensupları, aşırı sağ partilere oy vermekten geri durmazlar ve diğer tüm sivil müdahale alanlarında olduğu gibi oy vermede de parçalara ayrılıp oyun dışı kalırlar.

\section{Kentsel Eşitsizliğin Karşılaştırmalı Sosyolojisi İçin Bourdieucü Çerçeve}

Kent Paryalarl, yüzyıl dönümünde kentte yükselen yoksulluk rejiminin tarihsel modelini çizer. Çalışma, sürgünün karşılaştırmalı sosyolojisini, tek bir ulusal toplumun deneyimini diğer sınır aşırı toplumlarda analitik kıstas kabul etme tehlikesinden azade biçimde geliştirmek üzere tasarlanmış, getto, hipergetto, anti-getto, bölgesel damgalama, ileri marjinallik ve prekarya gibi kavramlar üretir. Kenti, sosyolojik bir araştırma nesnesi olarak inşa edebilmek için, Pierre Bourdieu'nün yaklaşımının altında yatan beş ilkeye başvurur. Kitabın olumlu eleştirilerinin dahi görmezden geldiği bu ilkelere daha yakından bakmakta fayda görüyorum. ${ }^{19}$

İlk ilke, kökleri doğrudan Gaston Bachelard ve Georges Canguilhem'in geliştirdiği bilim felsefesine uzanan ve Bourdieu tarafından sosyal araştırmaya uyarlanan tarihsel epistemolojiden türer: Gündelik kavramlarl, analitik kavramlardan net bir biçimde ayır; kendi kavramlarını üretebilmek için mevcut kavramların doğum sancılarını tekrarla ve ürettiğin kavramları ampirik 
karşılaşmalar aracılığıyla sonsuz bir akılcı düzeltme işlemine tabi tut (Bourdieu et al., 1991 [1968]; Broady, 1991). Kent Paryalari'yla başlayan ve gettoyu etnik kümelenmeden ve harabe bölgelerden farklılaştıran; tahsis edilmiş bölge (reservation), kamp ve hapishane gibi işlevsel benzerleriyle karşılaştıran; gettolaşmanın tabi nüfusun yapısal entegrasyonunda oynadığı paradoksal rolü vurgulayan The Two Faces of Ghetto'da (Gettonun İki Yüzü) nihayete erdirilen çift yüzlü bir etno-ırksal kapatma mekanizması olarak kurumsal getto kavrayışının arkasında böyle bir itki vardır (Wacquant, 2016). İkinci ilke, ilişkisel ya da topolojik akıl yürütme tarzını ifade eder ve burada sembolik uzam (faillerin dünyayı bilişsel ve gayretkeş inşalarını yönlendiren zihinsel kategoriler şebekesi), toplumsal uzam (toplumsal olarak etkin kaynakların ya da sermayelerin dağılımı) ve fiziksel uzam (maddi ve sembolik ürünleri mekân dolayımıyla sahiplenmek için sergilenen rekabetten doğan inşa edilmiş çevre) arasındaki çoğul bağlantıları ve dönüşümleri açıklı̆ga kavuşturur.

Üçüncü ilke, Bourdieu'nün radikal tarihselci ve çatışmacı eylem, yapı ve bilgi kavrayışını ifade eder: Bu ilke kentsel formları, çoğul zamansalıklar (uzun vadeli yapılardan [longue durèe], orta vadeli politik dönemlere ve kısa vadeli, kişilerin fenomenolojik ufuklarına ulaşan zamansallıklar) üzerinde verilen mücadelelerin ürünü, mahalli ve mükâfatı olarak kavramamızı mümkün kılar. Bu perspektiften bakıldığında, diğer toplumlardaki sürgün bölgelerinde olduğu gibi, Amerika'nın Kara Kuşağı ve Fransa'nın Kızıl Kuşağı, yükselişi ve çözülüşü kentte mekân, onur ve sınıf üzerinden verilen rekabetin yarattı̆̆ güç dengesi tarafından belirlenen, tarihsel bir tür olarak ortaya ç1karlar. Aynı şekilde, Amerikan metropolündeki hiper-getto ve Batı Avrupa'nın anti-gettoları, sistematik bir mantığın can verdiği sonsuz ömürlü varlıklar değildir. Tam tersine, doğuşu, gelişimi ve ani çözülüşü, özgün devlet ve vatandaşlık dokusu tarafından sürdürülen ya da kesintiye uğratılan, zamanın izini taşıyan yapılardır. Dördüncü ilke ise, etnografinin sıradan kültürel kategorilerin ve sosyal ilişkilerin yakından fotoğrafını çeken basit bir araçtan ziyade, bir kopuş ve kuramsal inşa aracı olarak kullanılmasını salık verir. Bu da, kuram ve yöntemin, geleneksel kentsel araştırmalardaki, mikroskobik gözlem ve makroskobik kavramsallaştırma ayrımına dayanan entelektüel işbölümünü tersyüz edecek biçimde iç içe geçmesini ifade eder. ${ }^{20}$

Sonuncu, fakat belki de en önemli ilke, sembolik yapıların teşkil edici gücüne dikkat çeker. Sembolik yapıların, bir taraftan kurumları teşkil eden nesnel konumlar ağı, diğer taraftan faillerin habitusunu oluşturan bedenselleş- 
miş eğilimler sistemi üzerindeki çifte etkisinin izini sürmeyi [telkin eder]. Bölgesel damgalama kavramının gösterdiği gibi, bu ilke özellikle kendi temsili üzerinde kontrolü olmayan ve bütün varoluşu üçüncü şahıslar, özellikle de siyasetçiler, gazeteciler ve sosyal bilimciler gibi otorite söylemiyle konuşan profesyoneller tarafından biçimlendirilen yoksun ve aşağılanmış nüfusun, örneğin kentsel prekaryanın analizinde oldukça faydalıdır. Şunu belirtmeliyim ki, marjinalliği inceleyen sosyolog, epistemik düşünümsellik ilkesine sadakatle bağlanmalı ve nesneleştirdiği kentin lanetli bölgeleri üzerinde verilen sınıflandırma mücadelelerinin içine çekilmemek için nesne üretiminin her aşamasında mutlak ihtiyatlı olmalıdır.

Bu beş ilke, Kent Paryaları'nda gösterildiği gibi, Atlantik aşırı metropollerin cehennem bölgelerinin analizinde sınıfsal dönüşüm (oluşum), onur derecelendirmeleri ve devlet politikaları arasındaki üçlü bağlantıya karşılaştırmalı bir ışık tutmaya sevk eder. Bu beş ilke aynı zamanda, sosyal güvencesizlik çağında sürgün bölgeleri sosyolojisinin kıtalar, kuramsal sınırlar ve kurumlar arasındaki üçlü genişlemesini verimli bir şekilde yönlendirebilir. Coğrafi olarak, [bu beş ilke] sosyo-tarihsel uyarlama ve kavramsal tadilat aracillğıyla, ileri marjinallik şablonunun, hem kapitalist merkezdeki ülkelere hem de kentsel ihtilafların hızla yayıldığı ve biçim değiştirdiği İkinci Dünya ülkelerine uyarlanmasına rehberlik edebilir. ${ }^{21}$ Kuramsal olarak, Bourdieu'nün özgün kavramlarını ve önermelerini kent mevzilerine getirmek, kent sosyolojisine hem meydan okuyan hem de bütünüyle yeni bir enerji katan kuvvetli bir kaynak sunar. ${ }^{22}$ Bunun anlamı, mevcut perspektiflere güçlü ve esnek, yeni bir kavram seti (habitus, alan, sermaye, sabit fikir, sembolik iktidar) eklemekle kısıtlı değildir. Bu aynı zamanda, kenti tarihi mücadelelerin merkezi ve ödülü kılan çeşitli sermaye türlerinin biriktiği, farklılaşttğı ve mücadele halinde olduğu bir bölge olarak yeniden kavramsallaştırmanın önünü açar.

Kurumsal cephede, yeni kentsel marjinallik rejiminin güçlenmesi, yoksulluğu dizginlemek, sınırlandırmak veya azaltmak iddiasındaki hükümetlerin paradoksal bir şekilde ekonomik kuralsızlaşma (ya da ekonomiyi şirketler lehine yeniden düzenleme), refah kesintisi ve kentsel tasarruf yoluyla yoksulluğu yaygınlaştırmasına yol açan politik müdahaleler tam teşekküllü bir analizi bekliyor. Başka bir deyişle, kurumsal cephede kentsel marjinalliğin değişen formlarının devlet inşasının yeni yöntemleriyle bağının kurulması gerekir. Diğer kitabım Punishing the Poor'da, Bourdieu'nün bürokratik alan kavramından faydalanarak çalışma refahıyla, giderek genişleyen hapishane refahının kutuplaşmış metropolün sorunlu bölgelerinde ve kategorilerinde ya- 
yılan tek bir örgütsel ve kültürel karışım haline gelmesine dayanan, yoksulluğun yönetiminde cezai tarzın icadını inceliyorum (Wacquant, 2009b ve 2012; yoksulluğu cezalandırmanın neoliberal politika transferinin merkezi bir unsuru olarak uluslararası yayılımı hakkında bir analiz için bkz. Wacquant, 2009c). Sanayi-sonrası işçi sınıfının prekaryalaşmış ve damgalanmış kesimlerinin yoğunlaştığı kentsel ihmalkârlık bölgeleri, neoliberal Leviathan'ın ana hedefi olduğu kadar, aynı zamanda inşa edildiği ve işleyişe geçtiği test birimidir. Dolayısıyla, sürgün bölgelerinin analizi kent sosyologları için olduğu kadar, devlet iktidarı kuramcıları için ve 21. yüzyıl kentlerinde sosyal adaleti geliştirebilmek için harekete geçen vatandaşlar için de acil bir ihtiyaçtir.

\section{Finansal Destek Notu}

Bu araştırma, Mac Arthur Vakfı, Harvard Üniversitesi W. E. B. Du Bois Enstitüsü ve Leverhulme Vakfínın İleri Kentsel Marjinalliğin Karşılaştırmalı Analizi üzerine verdiği burs tarafından desteklenmiştir.

\footnotetext{
${ }^{1}$ Bu projenin biyografik, analitik ve sivil zemini için bkz.: (Wacquant, 2009a), özellikle ss. 106110.

2 'Topluluk' kavramının Birleşik Devletler tarihinde yüklendiği anlamlar ve ifade ettiği belirsizliğin tarihsel bir özeti için bkz.: Bender (1978).

${ }^{3}$ Kent hayatına dair akademik ve sıradan bakış açılarının iç içe geçmesi ve bulanıklaşması Peter Hall'un (1988) Cities of Tomorrow ve Setha Low'un (1996) ‘The Anthropology of Cities: Imagining and Theorizing the City' eserlerinde vurgulanur.

4 'Beyaz kent içinde paralel siyah kenti', St. Claire Drake ve Horace Cayton'ın (1993 [1945] Black Metropolis: A Study of Negro Life in a Northern City başlıklı klasik çalışmasında tasvir edilir.

5 'Mahalle'nin kaderi ve normları üzerine verilen bir rekabeti ve karşılaşmayı tetikleyen bu mekânsal ve sosyal farklılaşma, Black Picket Fences: Privilege and Peril Among the Black Middle Class (2000) ve Black on the Block: The Politics of Race and Class in the City (2007) başlıklı çalışmalarıyla, kendi kuşağının önde gelen sosyologlarından Mary Pattilo tarafından incelenmniştir.

${ }^{6}$ Bu durum, 2010'da Danimarka hükümetinin 'paralel topluluklarla mücadele' planını duyuran, dönemin başbakanı Lökke Rasmussen' in kafa karıştırıcı açıklamalarıyla ispatlanmıştır. Sözünü ettiğim plan, göç, işsizlik ve suçun şaşırtıcı birlikteliğinin betimlediği, resmi olarak tasarlanmış 29 gettoyu hedef almaktadır (bkz. Rasmussen (2010), özellikle ss.: 1-7 ve 37-39).

${ }^{7}$ Kent toplumunun lanetlenmiş hissesi olarak, kentin tekinsiz muhitlerinin ya da yeraltı dünyasının kültürel üretimine dair çok yönlü bir inceleme için bkz.: Dominique Khalifa (2013) Les Basfonds. Historie d'un imaginaire.

${ }^{8}$ Gettonun özgün yapısı ve işlevi hakkında daha ayrıntılı bir tartışma için bkz.: Wacquant (2011)

'A Janus-Faced Institution of Ethnoracial Closure' ve Wacquant (2008b).
} 


\begin{abstract}
${ }^{9}$ Kita Avrupa'sının genel manzarası için bkz:: Pan KéShon ve Wacquant (2012) ‘Le Grand hiatus: tableau raisonné de la ségrégation ethnique en Europe'. Danimarka' daki durum için bkz.: Skifter (2010).

${ }^{10} \mathrm{Bu}$ üç düzlemi yıkmak, kolektif vicdanı, sosyal morfoloji, elit söylemi ve gündelik hayat davranışıyla birleştirip, tıpkı Jean Loup Amselle' in L'Ethnicisation de la France (2011) başlıklı çalışmasında yaptığı gibi, etnisitenin hayat şanslarının belirleniminde sahip olduğu potansiyelin ve orjinalliğin mekanik bir şekilde abartılmasına yol açar.

${ }^{11}$ Bu yaklaşımın tahrik edici bir yeniden yorumu için bkz.: Banton (2007).

${ }^{12}$ Etnisiteyi, onu kesen sosyal formlar ve ölçütlerle ilişki içinde inceleyen örnek bir çalışma için bkz.: Brubaker et al. (2008); konuya ilişkin analitik bir yorum için bkz.: Wimmer (2013).

${ }^{13}$ İlginç bir biçimde, bu tez Kent Paryaları üzerine City (Aralık 2007, Nisan 2008), International Journal of Urban and Regional Research (Eylül 2009), Reoue française de sociologie (Aralık 2009), Pensar (Kış 2009) ve Urban Geography (Şubat 2010) dergilerince düzenlenmiş sempozyumlarda neredeyse tamamen görmezden gelindi. Genel eğilim, kitabın karşılaştırma gündemini ıskalayarak, siyah gettonun tanımlanması ya da Fransız/Avrupa banliyösünün evrimine odaklanmak yönündeydi. ${ }^{14}$ Konuyla ilgili geniş bir manzara için bkz.: Andress ve Lohmann (2008); Clerc (2004); Shipler (2004). Danimarka örneği için bkz.: Hansen (2010). Birleşik Devletler'de icat edilen 'çalışan yoksul' kategorisi Fransa'nun resmi istatistiklerine 1996'da, Avrupa Birliği İstatistiklerine 2003'te ve Alman hükümetinin raporlarına 2009' da girdi.

${ }^{15} \mathrm{Bu}$ çalışmalarda ekonomik ve siyasi büyük yapılara karşı inşa edilmiş körlük Slater'ın (2013) çalışmasında vurgulanır.

${ }^{16}$ Konuya ilişkin makaleler ve geniş çaplı bir kaynakça için bkz.: Slater et al. (2014). Danimarka örneği için bkz.: Qvotrup Jensen ve Christensen (2012); Sernhede (2009).

${ }^{17}$ Nisan 2011'de Ayrımcılığa Karşı ve Eşitlik İçin Mücadele Yüksek Konseyi (HALDE), giderek yaygınlaşan 'adres temelli ayrımcılığa' karşı Fransız hükümetine, emek yasasına ayrımcllı̆ı engellemek için konulmuş 18 kritere, ikamet konumunu da eklenmesini tavsiye etti.

${ }^{18}$ Danimarka' da resmi olarak getto-bölgesi olarak tanınmış ve böylelikle harabeliğinin üzeri örtülmüş 29 bölgeyi kapsayan bir araştırma için bkz.: Schultz Larsen (2011).

${ }^{19}$ Önemli bir istisna için bkz.: Delica (2011). Bu beş ilkenin açıklanıp örneklendirilmesi için bkz.: Bourdieu ve Wacquant (1992).

${ }^{20}$ İngilizce konuşulan ülkelerin akademilerinde 'kent etnografisi' olarak bilinen araştırma alanı, sanki yönlendirici bir analitik model olmaksızın herhangi bir konuya dair gömülü gözlem yapmak mümkünmüş gibi, eğlenceli bir şekilde kuram dışıdır. Kentsel dönüşümleri inceleyen büyük kuramlar ise, yapısal güçlerin gündelik eylem ve anlam kalıplarını nasıl biçimlendirdiğiyle ilgilenmezler. Kent Paryaları'nın amaçlarından biri bu uçurumu kapatmak ve saha gözlemleri, kurumsal karşılaştırma ve makroskobik kuram arasındaki devamlı iletişimden doğacak ampirik ve kavramsal faydaya dikkat çekmektir.

${ }^{21}$ İngiltere örneği için bkz:: Atkinson et al. (2010); Güney Afrika, Brezilya ve Çin uyarlamaları için sırasıyla bkz.: Murray (2011); Perlman (2010); Wu ve Webster (2011). İnterdisipliner bir platformla bağlantılı araştırmacıların çeşitli çalışmaları için bkz.: www.advancedurbanmarginality.com

${ }^{22}$ Bourdieu ve kent ilişkisine dair çeşitli katkılar için International Journal of Urban and Regional Research'ün (Kış 2018) ‘Bourdieu’yü Kente Getirmek’ temalı özel sayısına bakınız.
\end{abstract}

\title{
Kaynakça/References
}

Amselle, J-L (2011). L'etnicisation de la France. Fécamp: Nouvelles Éditions Lignes. 
Andress, H-J ve Lohmann, H. (der.) (2008). The working poor in Europe: Employment, powerty and globalization. Cheltenham: Elgar Publishing.

Atkinson, W., Roberts, S. ve Savage, M. (der.) (2012). Class inequality in austerity Britain: Power, difference and suffering. Basingstoke: Palgrave Macmillan.

Banton, M. (2007). Max Weber on 'ethnic communities': A critique. Nations and Nationalism 13(1): 19-35.

Bender, T. (1978). Community and social change in America. New Brunswick, NJ: Rutgers University Press.

Bourdieu, P. (1990). Language and symbolic power. Cambridge: Polity Press.

Bourdieu, P. Ve Wacquant, L. (1992). An invitation to reflexive sociology. Chicago: University of Chicago Press.

Bourdieu, P., Chamboredon, J. C. Ve Passeron, J. C. (1991[1968]). The craft of sociology: Epistemological preliminaries. New York: Walter de Gruyter.

Broady, D. (1991). Sociologi och epistemologi: Om Pierre Bourdieus sociologi och den historiska epistemologin. Stockholm: HLS Förlag.

Brubaker, R., Feischmidt, M., Fox, J. et al. (2008). Nationalist politics and everyday ethnicity in a transylvanian town. Princeton: Princeton University Press.

Cingolani, P. (2011). La Précarité. Paris: PUF.

Clerc, D. (2004). La France des traveilleurs pauvres. Paris: Grasset.

Delica, K. (2011). Sociologisk refleksivitet og feltanalytisk anvendelse af etnografi: Om Loïc Wacquants blik pa urban marginalisering. Dansk Sociologi 22(1): 47-67.

Drake, S. C. ve Cayton, H. (1993[1945]). Black metropolis: A study of negro life in a northern city. Chicago: University of Chicago Press.

Goffman, E. (1964). Stigma: Notes on the management of spoiled identity. Englewood Cliffs: Prentice-Hall.

Hall, P. (1988). Cities of tomorrow: An intellectual history of urban planning and design in twentieth century. Oxford: Blackwell.

Hansen, F. K. (2010). Fattigdom i EU-landene-og dansk fattigdom i europerisk perspektiv. Copenhagen: CASA.

Kalifa, D. (2013). Les Bas-fonds: Histoire d'un imaginaire. Paris: Seul.

Kalleberg, A. L. (2011). Good Jobs, Bad Jobs: The rise of polarized and precarious employment systems in United States, 1970s-2000s. New York: Russel Sage Foundation.

Liogier, R. (2012). Le Mythe de l'islamisation: Essai sur une obsession collective Mythe. Paris: Seuil.

Low, S. (1996). The anthropology of cities: Imagining and theorizing the city. Annual Review of Anthropology 25: 383-409.

Massey, D ve Denton, N. (1993). American apartheid: Segregation and the making of underclass. Cambridge: Harvard University Press.

Murray, M. J. (2011). City of extremes: The spatial politics of Johannesburg. Durham: Duke University Press Books.

Maurin, L. ve Savidan, P. (2008). L'État des inégalités en France 2009: Données et analyses. Paris: Belin. 
Perlman, j. (2010). Favela: Four decades of living on the edge in Rio de Janario. New York: Oxford University Press.

Pan Ké Shon, J. L. ve Wacquant, L. (2012). Le grand hiatus: Tableau raisonné de la ségrégation ethnique en Europe. Institut national d'études démographiques tarafından düzenlenen 'Sosyo-etnik ayrımcılık: Dinamikleri ve sonuçları' temalı etkinlikte sunulan makale, Paris, 13 Haziran. Daha detayl bilgi için bkz.: https://www.ined.fr/en/news/scientific-meetings/seminaries-colloque-ined/lasegregation-socio-ethnique-dynamiques -et-consequences/.

Pattillo, M. (2000). Black picket fences: Privilege and peril among black middle class. Chicago: University of Chicago Press.

Pattillo, M. (2007). Black on the block: The politics of race and class in the city. Chicago: University of Chicago Press.

Pelizzari, A. (2009). Dynamiken der prekarisierung: Atypische erwerbsverhältnisse und milieuspezifische unsicherheitsbewältigung. Konstanz: UVK Verlag.

Qvotrup Jensen, S. Ve Christensen, A. D. (2012). Teritorrial stigmatization and Local belonging. City 16(1-2): 74-92.

Rasmussen, L. (2010). Ghettoen tilbage til samfundet-et opgør med parallelsamfund i Danmark. Copenhagen: Regeringen.

Schultz, L. T. (2011). Med Wacquant i det ghettopolitiske felt. Dansk socioligi 22(1): 47-67.

Sernhede, O. (2009). Territorial stigmatisering: Unges uformelle læring og skolen i det postindustrielle samfund. Social Kritik 118: 5-23.

Shipler, D. K. (2004). The working poor: Invisible in America. New York: Knopf.

Skifter, A. H. (2010). Spatial assimilation in Denmark: Why do immigrants move to and from multi-ethnic neighborhoods.? Housing Studies 25(3): 281-300.

Slater, T. (2013). Your life chances affect where you live: A critique of the 'cottage industry' of neighborhood effects research. International Journal of Urban and Regional Research 37(2): 367-387.

Slater, T., Pereira, V. ve Wacquant, L. (der.) (2014). Special issue on 'territorial stigmatization in action'. Environment \& Planning D 46(6): 1263-1402.

(2018). Special issue: Bringing Bourdieu to town. International Journal of Urban and Regional Research.

Standing, G. (2011). The precariat: The new dangerous class. London: Bloomsbury.

Wacquant, L. (2008a). Urban outcasts: A comparative sociology of advanced marginality. Cambridge: Polity Press.

Wacquant, L. (2008b). Ghettos and anti-ghettos: An anatomy of the new urban poverty. Thesis Eleven 94(1): 113-118.

Wacquant, L. (2009a). The body, the ghetto and the penal state. Qualitative Sociology 32(1): 101-129.

Wacquant, L. (2009b). Punishing the poor: The neoliberal government of social insecurity. Durham: Duke University Press.

Wacquant, L. (2009c). Prisons of poverty. Minneapolis: University of Minneapolis Press. 
Wacquant, L. (2011). A janus-faced institution of ethno-racial closure: A sociological specification of the ghetto. Hutchinson, R. ve Haynes, B. (der.) içinde. The ghetto: Contemporary global issues and controversies. Boulder: Westview, ss. 1-31.

Wacquant, L. (2012). Crafting the neoliberal state: Workfare, prisonfare and social insecurity. Sociological Forum 25(2): 197-220.

Wacquant, L. (2016). The two faces of the ghetto. New York: Oxford University Press.

Wilson, W. J. (1996). When work disappears: The world of the new urban poor. New York: Knopf.

Wimmer, A. (2013). Ethnic boundary making: Institutions, power, networks. New York: Oxford University Press.

Wu, F. ve Webster, C. (der.) (2010). Marginalization in urban China: Comparative Perspectives. New York: Palgrave Macmillan.

Loïc Wacquant Berkeley'deki California Üniversitesi kampüsünde sosyoloji profesörü ve Paris'teki Avrupa Sosyoloji Merkezi'nde araştırmacıdır. Temel ilgi alanları, kentsel marjinallik, ceza, bedensellik ve toplum kuramıdır. MacArthur Ödülü'nü kazanan Wacquant'ın yirmiden fazla dile tercüme edilmiş kitaplarından bazıları şunlardir: Body and Soul: Notebooks of An Apprentice Boxer (2004, yeni genişletilmiş bask1, 2016), The Two Faces of the Ghetto (2016), ve Tracking the Penal State (2016). Daha fazla bilgi için yazarın kişisel internet sitesi olan loicwacquant.net'i ziyaret edebilirsiniz.

Loïc Wacquant is professor of sociology at the University of California, Berkeley, and researcher at the Centre de sociologie européenne, Paris. His interests include urban marginality, penality, carnality, and social theory. A MacArthur Prize Fellow, his books have been translated in two dozen languages and include Body and Soul: Notebooks of An Apprentice Boxer (2004, new expanded edition, 2016), The Two Faces of the Ghetto (2016), and Tracking the Penal State (2016). For more information, see loicwacquant.net. 